\title{
MÜVÉSZETTUDOMÁNY
}

\section{Kolosai Nedda}

Eötvös Loránd Tudományegyetem, Tanító- és Óvóképző Kar

\section{Múvészet és tudomány}

Már tudom az összes eredményt, de még nem tudom, hogyan kapom majd meg öket. Minden idők legnagyobb matematikus lángelméje Carl Friedrich Gauss éppen egyik kéziratán dolgozott - aminek leadásával igencsak elkésett -, amikor barátai megkérdezték tőle, mégis hogyan halad munkájában. Gauss nekik válaszolta, fent idézett, elgondolkodtató mondatát ${ }^{1}$.

Általános tapasztalata a pszichológiának, valamint a múvészeti nevelést vizsgáló kutatásoknak, milyen nagy hatással van a személyiség alakulására a müvészetekkel való foglalkozás. A müvészeti tevékenységek transzferhatása pozitívan befolyásolja bizonyos tanulási képességek alakulását (Kárpáti, 1991; Laczó, 2001; Trencsényi, 2002; Thurmezeyné és Balogh, 2009).

Müvészet és tudomány, müvészet és tanulás kapcsolata egyértelmü, mégis izgalmas, fontos tevékenység annak átgondolása és bizonyítása, miben is ragadható meg egymásra hatásuk lényege. Mielőtt belekezdenék a müvészetek tanulást segítő, személyiségformáló hatásának aprólékos bemutatásába, egy érdekes kitérőt szeretnék tenni annak rövid átgondolására, milyen kapcsolatban is van egymással tudomány, alkotó gondolkodás és müvészet.

Sokan már e két fogalom - tudomány és müvészet - egymás mellé helyezésén is csodálkoznak, szerintem most mindannyian látjuk lelki szemeink előtt, fontoskodóan grimaszoló arcukat. Hiszen a fizikai világ meghatározott, a (természet)tudományban a fizikai események rögzítőjének, személyének alig van jelentősége, az univerzum törvényeit a szubjektum nem változtathatja meg. A (természet)tudomány a hideg, egyértelmü tényekkel dolgozik, nem értékekkel foglalkozik, az alkotó müvészetek viszont nem létezhetnek értékítélet nélkül. A müvészetben a tiszta ész logikus következtetései helyén, a megértés érzelmi, szubjektív, intuitív formája áll ${ }^{2}$.

Tény, hogy a tudományos eredményeket logikai alapon sajátítjuk el, ám vajon igaz-e, hogy azok így is keletkeznek? A logikus levezetés szerepét a tudományos felfedezésekben könnyü túlbecsülni (Einstein, 1994), ezért is választottam Gauss életpéldájával, egy matematikai összefüggésrendszer intuitív megtalálásának esetét. Lánczos Kornél (1973/2011) magyar származású, angol fizikus, matematikus, Albert Einstein egyik matematikatanára, kiemelkedő természettudományos felfedezések megalkotóinak életrajzát tanulmányozta. Arra a megállapításra jutott, hogy minden nagy tudományos felfedezés tudományos képzelőerőt, a müvészeti alkotáshoz hasonlatos inspirációt igényelt, valamint

\footnotetext{
${ }^{1}$ http://members.iif.hu/visontay/ponticulus/rovatok/hidverok/lanczos.html

${ }^{2} \mathrm{http} / / /$ members.iif.hu/visontay/ponticulus/rovatok/hidverok/lanczos.html
} 
legtöbbször az elött megszületett, mielőtt logikai alapon azt bizonyították ${ }^{3}$. Ebben a kontextusban a legkiválóbb (alkotó) tudósok, felfedezők, a legkiválóbb alkotó múvészekhez hasonlatos módon építik fel, alkotják meg a világ (természet)tudományos leírását (Atkinson és Hilgard, 2005). Albert Einstein (1994) óta a fizikai világ esztétikai és filozófiai jellege megkérdőjelezhetetlen ${ }^{4}$, az alkotó, a produktív tudományt már nem lehet visszacsúsztatni abba a pozícióba, ahol a tényeket elöítéletek nélkül, értékmentesen, sina ira et studio ${ }^{5}$ vizsgálják.

Tudomány és müvészet lényegi összefüggéseire mutat rá a művészeti alkotások és a nagy tudományos felfedezések között található figyelemre méltó párhuzamosságok átgondolása. A téma érdemes a kitüntetett figyelemre, mivel általában a tudománnyal foglalkozó diskurzusok leegyszerüsített kérdése az, vajon a tudományos megismerés objektív avagy szubjektív müvelet-e? A leginkább sematizáló polaritás a tudományos megismerés kvantitatív versus kvalitatív szembeállítása. Számomra, jelenlegi gondolkodásomban, Hans-Georg Gadamer felfogása az emberi megismerésről a legpontosabban átgondolt felfogás. Gadamer (1984) Martin Heideggert (2001) és Wilhelm Diltheyt (2004) követve arra vállalkozik, hogy az igazságra és annak megismerésére vonatkozó kérdést újra írja a müvészeti és történelmi tapasztalat felől közelítve (Mészáros, 2010). Gadamer hermeneutikai szituációról beszél, melynek lényege, hogy minden időpillanatban adott élethelyzetünk és nézőpontunk foglyai vagyunk, így adott horizontunk, látókörünk meghatározza, hogy mindig csak megfelelő irányban és szögben látunk rá az eseményekre (Gadamer, 1984). A megismerés mindig összekapcsolódik azzal, aki megérti; a kutatóval, az olvasóval, a mü átélőjével. A tudomány sem objektív és előfeltevések nélküli megismerés, a világértelmezésben mindig ott van a tudós, sajátos világlátásával, világértelmezésével, saját perspektívájával, kultúra értelmezésével, ahogyan a müvészeti alkotás is egyszerre tartalmazza alkotója valamint aktuális befogadója értelmezési tartományait.

Az antropológus Cliffort Geertz (1994) szemléletes példát hoz kutatásaiból, mindezek megértésére. Elképzelhető, hogy valaki tikkel. Azonban szándékosan becsukni az egyik szemünket, miközben van egy társadalmi szabály, mely szerint ez olyan titkos jelnek számít, mellyel egy bizonyos személynek meghatározott üzenetet adunk át, anélkül, hogy a társaság többi tagja erről értesülne - ez maga a kacsintás mondja Geertz. Leírhatjuk statisztikai módszerekkel a tikkelő és a kacsintó pislogásainak számát, ezzel a pillanatfelvétellel azonban nem érzékeltethetjük a mozdulatok között lévő alapvető és lényegi eltérést. Mindenki tudja ezt, aki balszerencséjére az elsőt valaha a másodiknak hitte (Geertz, 1994).

A 20. századi hermeneutika ontológiai fordulatának fényében a megértés nem puszta megismerés, sokkal inkább létmód. A hermeneutika így nem szükíthető le puszta tudományelméletre. Természetesen nincs okunk lemondani az értelmezés hitelességéröl. Voltaképpeni célja és értelme a hermeneutikai megértésnek azonban mégis az, hogy önmegértéshez, önértelmezéshez segít,

\footnotetext{
${ }^{3}$ http://members.iif.hu/visontay/ponticulus/rovatok/hidverok/lanczos.html

${ }_{5}^{4} \mathrm{http}: / /$ members.iif.hu/visontay/ponticulus/rovatok/hidverok/lanczos.html

${ }^{5}$ Harag és ellenkezés nélkül.
} 
ember-, személyiség- és közösségformáló szerepet tölt be. Általa leszünk tulajdonképpen azzá, akik vagyunk (Fehér M., 2009; Loboczky, 2009). Gondolatmenetemmel komoly szándékom tudományos és müvészi megismerés alapvető hasonlóságának, sőt párhuzamosságának megmutatása, valamint a „két kultúra" elmélettől való óvatos távolodás.

\section{Miért pont múvészet?}

Fontos kérdések sorjáznak a fejemben. Mi a müvészet? Mi haszna lehet a müvészetek müvelésének a mindennapi pedagógiai munkában? Ki a művész? Hogyan segíti a müvészetek tevékeny végzése a tanulási folyamatokat? A feltett kérdésekre nem szándékom teljes válaszokat adni, némelyiket meghagyom költői kérdésnek, valamint további kérdésekkel folytatom a sort hamarosan. Munkám szempontjából lényegesnek tartom, hogy egyszerüen gondolkodjunk rajtuk.

Tudjuk, hogy az esztétikai élmény, - az aktív vagy „passzív” művészeti tevékenység - személyiségformáló, nevelő hatással van az emberre, különösképpen a gyermekre, de nem vesszük komolyan, kevéssé reflektáljuk tudományos gondolkodásunkban, milyen mély és maradandó ez a nevelö hatás. A müvészetekkel való találkozás különleges helyet foglal el jelenkori életünkben. Mindennapi tapasztalatunk, hogy felnőtt életünk napjait többé-kevésbé automatikus cselekvések, már-már lélektelen algoritmusok sora teszi ki. Mindennapi rutincselekvéseink végzésekor fontos a koncentráció, de érzékeink, érzékszerveink, érzelmi életünk eközben csak kicsit mozdul. Müvészeti tevékenységet; egy szobor megformálását, hangszeres zenemü begyakorlását, színpadi szerep eljátszását nem lehet rutinból végezni. Alkotni testi-lelki odaadással kell (Klinborg és Calgren, 2003).

Lev Tolsztoj (2010) egy emberöltőt gondolkodott azon, vajon miben is ragadható meg a müvészet lényege. Számtalan megközelítést megvizsgált, melyek a müvészet szubsztanciáját kutatták. Mindezekből és saját tapasztalataiból következtetve arra jutott, hogy a müvészet nem csupán a szépség élvezetének egyik eszköze, hanem az emberi élet feltétele. A müvészet az emberek közti érintkezésnek egyik módja, párbeszéd szavak nélkül. A művészeti tevékenység lényegét képezi, hogy az alkotó tudatosan, bizonyos jelek alkalmazásával (mozdulattal, színnel, hanggal, dallammal, ritmussal, vonallal, kővel, szóval) közli az általa átélt érzéseket, melyek másokat is megérintenek. Ebben a kultúrák, történeti korok, társadalmi rétegek közötti párbeszédben a müvészet érthetővé, világossá tesz valamit, ami szavakkal kifejezve még homályos volt, olyan dolgokat értünk meg általa, melyeket elötte nem értettünk (Tolsztoj, 2010). Tolsztoj gondolatait mint munkadefiníciót fogadom el, elismerve megközelítésének kiegészíthetőségét, továbbgondolhatóságát. Umberto Eco más perspektívából közelít a müvészet lényegéhez, szerinte a müvészettel kapcsolatos tudás nem más, mint a szabályok ismerete a dolgok készítésével kapcsolatban, ebben az értelmezésben a müvészi kifejezésmód, a müvészi közlés mibenléte szabályozott, mivel egyetemes gondolatokat tükröz (Eco, 2002 idézi EndrődyNagy, 2013). Lánczos Kornél müvészet és tudomány értelmezése közel áll 
egymáshoz. Az ember a dolgokat, a világot akár az igazság, akár a szépség világában, nem olyannak igyekszik megérteni, amilyenek, hanem amilyennek lenniük kell (Lánczos, 1973/2011). Ez a megközelítés hasonlít Eco gondolatára, mely szerint a müvészet egyetemes igazságok tükrözése.

Mi a mủvészetpedagógia feladata, jelentősége? A müvészetpedagógia maga értékközvetítés (Trencsényi, 1991; 2000). A müvészet segítségével alakuló párbeszédben az értékközlés egyben identitásközlés, az értékek cseréje mediálja a társadalom értékhordozó csoportjainak közeledését. „A müvészet, az esztétikum, a művészi nyelv könnyíti ezt a közeledést, ezzel segíti a társadalmi integrációt". (Trencsényi, 2000. 28. o.). További kérdéseim költőiek: Ki a művész? Mi a szemléletbeli különbség lényege a müvészeti nevelés és a müvészettel nevelés között? Hol van a finom határvonal a pszichológia és a pedagógia tudományának müvészetekhez közelítésében? Azaz, hol van a határ müvészetterápia és a múvészet személyiségformáló erejének pedagógiai felhasználása között? Utóbbi kérdésre például Illés Anikó (2009) és Kiss Virág (2013) adnak részletes válaszokat tanulmányaikban.

Jelen tanulmányban a legfontosabb kérdés, ahonnan közelítek, a következö: Miért járnak a gyerekek iskolába és óvodába? Mit vár el egy szülő, milyen legyen az ő iskolás, óvodás gyereke? Vajon mit vár el az iskola, milyen legyen, milyenné váljon az oda járó gyerek? Érdekes lenne egyszer megkérdezni a gyerekeket, meghallgatni a hangjukat arról, milyen legyen az iskola, miért járnak a gyerekek iskolába és óvodába szívesen. Vannak iskolák, ahol már belépéskor felteszik ezeket a fontos kérdéseket a szülöknek. A válaszok sokrétüek, gazdagon árnyaltak, mégis összegezhetők abban, hogy a szülő elvárása szerint, az iskola és az óvoda legyen alkalmas közeg arra, hogy gyermekük kibontakoztathassa önmagát, váljon azzá, amivé saját képességei predesztinálják, emellett legyen kiegyensúlyozott, legyen boldog. Az iskola szintén leegyszerüsített válasza erre a kérdésre az, hogy tudjon és tanuljon minél többet a gyermek, minél maradandóbb, elmélyültebb tudásra tegyen szert, annak érdekében, hogy megállja majd a helyét az életben, akár továbbtanulásról, akár a való életben való eligazodásról van szó (Kolosai, 2013). Kérdés, milyen elképzelései, módszerei vannak az iskolának és az óvodának ahhoz, hogy elérje ezt a célját? Kérdés az is, hogy az iskola és az óvoda által kitüzött célok vajon összeegyeztethetők-e a szülők céljával, boldog lesz-e a gyermek, pontosabban képes lesz-e örömmel tevékenykedni, örömmel, kíváncsian tanulni, később így élni?

Évtizedek óta pontosan tudjuk, hogy az intelligencia nehezen meghatározható fogalma nem csak a verbális, nem csak az absztrakt logikaimatematikai tudást és nem csupán a megtanult ismeretek visszaadásának képességét jelenti. Howard Gardner már 1985-ben leírta akkor még provokatívnak számító elméletét, mely szerint nincs egységes intelligencia, legalább hatféle elkülönült területe van az intelligenciának, melyek egymástól függetlenül müködnek. Gardner a nyelvi, a logikai-matematikai és téri intelligencia mellett megkülönböztette a zenei, a testi-kinesztéziás és a személyes 
intelligenciát, utóbbin belül pedig elkülöníti az interperszonális és az intraperszonális intelligenciát (Gardner, 1993).

Melyik az az iskola és óvoda, amelyik figyelembe veszi ezt a tényt és megadja a lehetőséget a különböző intelligenciaterületek gyakorlásához? Szerencsére egyre több van belölük szakemberek és szülök együttes kezdeményezésére. A szemléletformálásban felvállaltan nagy szerepe van az ELTE Tanító- és Óvóképző Karának, ahol minden tanszék hangsúlyozza az 1-12 éves korosztály tevékenységeken, mozgáson, müvészeteken keresztül való nevelésének egyben tanításának fontosságát (például: Bánki és Bálványos, 2005; Mikonya, 2013; Döbrössy, 2011; Bakos, Bálványos, Preisinger és Sándor, 2012; Kismartony, 2012; Pataky, 2012; Darvay, 2012).

Szakmai vitákban felmerül a kérdés, vajon korszerü, hatékony ez a szemlélet? Nem ódivatú színdarabokat írni, tanulni, játszani, furulyázni, ad abszurdum kézzel rajzolni és eleven emberi szóval mesélni az internet és az elektronikus média korában? Izgalmas (de nem paradox) módon a természettudományos megismerést és kutatást, annak módszereit és eredményeit szükséges fehér zászlóként lengetni a szélben, hogy bizonyíthassuk a müvészeti tevékenység végzése az élet első tizenkét évében (és tovább) nem l'art pour l'art tevékenység, hanem maga a gyermeki tanulás.

\section{A tanulmány célja}

Dolgozatomban - az agykutatás legújabb eredményeinek szisztematikus áttekintésével - kísérletet teszek annak bizonyítására, hogy a müvészeti nevelés hatékonyan, szakszerüen segíti a gyermeki tanulást, egyben jelentős szerepe van a gyermek lelki egészségvédelmében. Így a müvészeti nevelés komplex hatásrendszerével egyszerre járul hozzá az iskola, az óvoda és a szülök céljainak maradéktalan teljesítéséhez.

\section{Agykutatások és müvészeti nevelés}

Magyarországon Feund Tamás ${ }^{6}$ Bolyai-díjas professzor, nemzetközi hírü agykutató, jelenleg az MTA Kísérleti Orvostudományi Kutatóintézet igazgatója, a Pázmány Péter Katolikus Egyetem tanszékvezető egyetemi tanára, a FENS (Európai Idegtudományi Társaságok Szövetsége) volt elnöke végzett a témába vágó kutatásokat. Németországban pedig többek között Gerald Hüther agykutató és neurobiológus a Neurobiological Research Unit at the Psychiatric Department, University of Göttingen, valamint a Center of Neurobiological Prevention Research at the University of Göttingen vezetöjének híres kutatásai örvendenek népszerüségnek. Tudatosan Freund Tamás és Gerald Hüther professzorok évtizedek óta folyó kutatásaira építem fel munkámat és annak üzenetét.

\footnotetext{
${ }^{6}$ Freund Tamás 2011-ben - Buzsáki Györy és Somogyi Péter agykutatókkal együtt - elnyerte a dán Grete Lundbeck Európai Agykutató Alapítvány által alapított The Brain Prize díjat, amit az agykutatók Nobeldíjának is neveznek. http://zaol.hu/hetvege/az-agykutato-nobel-dija-1405677
} 

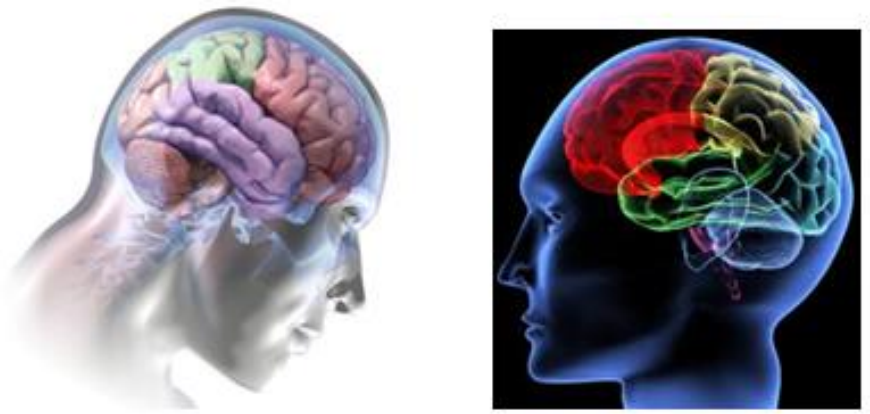

1. ábra

Agykutatás - utazás a koponyán belül
$\mathrm{Az}$ emberi agy

kutatása szempontjából azért különleges jelentőségü a kreativitás és a tanulás folyamatainak vizsgálata (1. ábra $\left.{ }^{7}\right)$, mert agyunk képes arra, hogy a múlt tapasztalatai alapján értelmezze a jelent és

elképzelje a jövőt ${ }^{8}$. Múlt-jelen-jövő folyamatos, a múlt ismeretei és felhalmozott tapasztalata alapján a mindenkori jelen perspektívájából alakítjuk ki jövőnk elvárás horizontját (Koselleck, 2003). A ma a tegnap holnapja. A ma a holnap tegnapja. Számos párhuzamos idősíkban képesek vagyunk nagy mennyiségü információt elraktározni, ezeknek az idősíkoknak a párhuzamos megtöltése memórianyomokkal elképesztő mennyiségű információ tárolását teszi lehetővé, Marcel Proust nyomán az ember esetében a tudás Atlantiszairól beszélhetünk (Proust, 2009). A rengeteg információ elraktározása követelte meg az evolúciótól, hogy sok és mély barázda létrehozásával több négyzetméternyire növelje az emberi agy felszínét ${ }^{9}$.

Az idegrendszer elemi egységei (axonok, idegsejtek, szinapszisok) nem állandó erősségüek, a használattól függően erösödnek vagy gyengülnek. Egy elemi információ, egy memórianyom is több százmillió sejtkapcsolatot igényel (Fonyó, 2011).

A gyermeki agyban rendelkezésre álló sokféle és alapvetően fontos neuronális áramkör kialakításához és megtartásához, a memórianyomok kialakulásához és állandósulásához, a német Gerald Hüther agykutató és neurobiológus szerint, a gyermekeknek alapvető szükségük van egy olyan világ megtapasztalására, melyben ők maguk hatékony cselekvők, aktív résztvevők, mégpedig a valós élet összefüggéseiben - azaz nem virtuálisan (Hüther, 2009).

Néhány évvel ezelőtt a neurobiológusok a gondolkodásunkat, érzelmeinket, mozgásunkat, viselkedési repertoárunkat irányító komplex neuronális hálózatokat genetikailag programozottnak tartották. Mára egyértelművé vált, hogy a gyermeki agyban hosszú távon csak olyan neuronális kapcsolatok jönnek létre és maradnak fenn, melyek a konkrét életvilágban is rendszeresen aktiválódnak. A genetikai programok által biztosított idegsejtkapcsolatok közül azok, melyeket nem használ a gyermek, egyszerűen elsorvadnak (Hüther, 2009). Tehát a tanulás, gondolkodás, fogalomalkotás, problémamegoldás szempontjából alapvetően fontos az embergyerek számára a valódi világot megtapasztalni majd a tapasztalati alapján

\footnotetext{
${ }^{7}$ Bal oldali kép: http://dunaharasztima.hu/?p=18155, jobb oldali kép: http://www.ismertseg.hu/Arulkodoagyhullamaink

${ }^{8}$ http://www.unz.org/Pub/TEDxTalks-2011-01373

${ }^{9}$ http://www.unz.org/Pub/TEDxTalks-2011-01373
} 
értelmezni annak mélyebb összefüggéseit (Kolosai, 2011). A gyermeki agy úgy tanulja meg hatékonyságát, érti meg saját kompetenciáját, ha olyan valódi kihívások elé állítjuk, melyben valódi erőfeszítéseket kell tennie, valódi nehézségeket kell leküzdenie, müködtetnie kell fantáziáját, képzeletét. Felnőttként, pedagógusként lehetőségeket kell biztosítanunk a gyermeknek a tapasztalásra, a megmászásra, tapintásra, ízlelésre, mozgásra, az egész testével, érzékszerveivel és képzeletével együttesen végzett tevékenységek rendszeres végzésére (Hüther, 2009; Kolosai, 2011).

Az agykutatások alapvető kérdése, vajon agyunk szerkezete, hogyan jósolja meg annak müködését?

Freund Tamás azt mondja, hogy a kéreg alatti ösi központokban elhelyezkedő szupergátló ${ }^{10}$ sejtek (2. ábra) képesek szinkronizálni az agykéreg müködését, szabályozni az agykérgi hullámtevékenységeket, azaz hatékonyan szabályozzák az egész agykérget befolyásoló több tízmilliárd idegsejt müködését. Úgy müködnek, mint egy jó főnök. Képesek befolyásolni, melyik érzékszervi információt analizáló agyi területünkön lesz maximális az az agyhullám tevékenység, amelynek következtében a figyelmünk szelektál, a memórianyomok rögzülnek, az éberség, aktivitás élettanilag megfelelő lesz ${ }^{11}$.

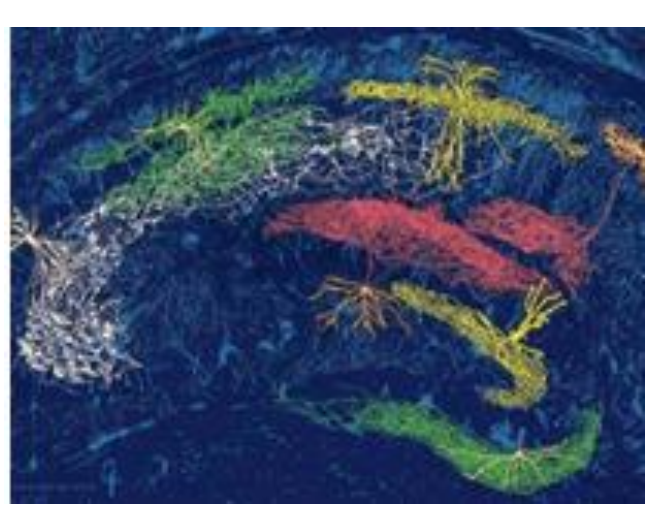

2. ábra

Megfestett szupergátló sejtek

Itt most fontos megvizsgálnunk, mit is jelent az agyi alapaktivitási szint, az arousal szint, melyet Freund Tamás agyi hullámtevékenységnek nevez. Kutatások szerint az ember egy optimális agyi alapaktivitási szint beállítására törekszik, amely a psziché leghatékonyabb müködését, a legkellemesebb közérzetet, a leghatékonyabb tanulást és teljesítményt biztosítja számára. Az agy optimális állapotához, müködéséhez, arra van szükség, hogy az agyi alapaktivitás, az úgynevezett arousalszint megfelelő legyen (Yerkes-Dodson, 1908 idézi: Szabó, 2004).

Ez annyit jelent, hogy ha az agyi izgalmi-éberségi szint túl alacsony, mert éppen alszunk előadás közben, akkor nagyon kicsi a tanulási teljesítmény hatásfoka. Ugyanakkor azt is jelenti, hogy amikor túl magas az arousalszint, mert összevitatkoztunk valakivel, nagyon szerelmesek vagyunk satöbbi, akkor is alacsony figyelmi, tanulási, gondolkodási teljesítményre leszünk képesek. Az optimális arousalszint kifejezést helyettesíthetnénk a pozitív érzelmek vagy a megfelelö, cselekvésünket dinamizáló motiváció terminusával is (Szabó, 2004; Kolosai, 2011).

\footnotetext{
${ }^{10}$ Az MTA Kísérleti Orvostudományi Kutatóintézetében magyar agykutatók által kifejlesztett kétdimenziós lézermikroszkóp segítségével (kétfotonpásztázó), akár egyetlen idegsejten keresztül is tudjuk vizsgálni a gátló rendszer müködését.

${ }^{11}$ http://www.unz.org/Pub/TEDxTalks-2011-01373
} 


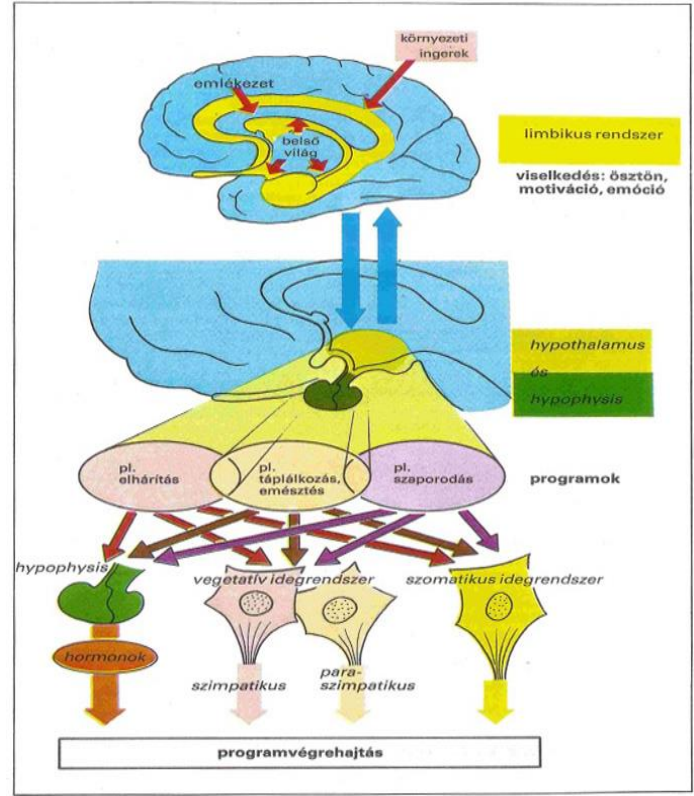

3. ábra

Limbikus rendszer

Nagyon lényeges ponthoz érkeztünk az áttekintésben: fontos tulajdonsága ezeknek az ösi központoknak, hogy a limbikus rendszeren (3. ábra ${ }^{12}$ ) keresztül kapcsolatban állnak belső világunkkal, érzelmeinkkel egyben motivációinkkal, melyek cselekvéseink hajtóerejeként szolgálnak. Hosszú távú memóriánkkal, viselkedésünkkel, a szaglás agyi központjával is közvetlen a kapcsolat, valamint aktuális élettani állapotunkról is szállítanak impulzusokat a kéreg alatti központok az agykéreghez ${ }^{13}$. A tanulás által kialakult emléknyomok megtartásáért tehát alacsonyabb rendü és magasabb rendű agyi struktúrák egyaránt felelősek. A hosszú távú memória tárolási szakaszára irányuló biológiai vizsgálatok segítségével sikerült meghatározni a konszolidáció neuroanatómiai alapjait. A tárolás folyamatában jelentős szerepet tölt be a konszolidáció, melynek fiziológiai alapjait számos agyi képleten kívül, elsősorban a hyppokampusz és az amygdala, ez a két kéreg alatti agyi struktúra képezi, valamint a hyppokampuszt körülvevő agykérgi területek, az entorhinális, perirhinális és parahippokampális kéreg, amelyek a hyppokampusz és az agykéreg közötti információcserében játszanak szerepet. Kutatások valószínüsítik, hogy a hyppokampusz konszolidációban betöltött funkciója az, hogy egyfajta vonatkoztatási- és kereszthivatkozási rendszert valósít meg, összekapcsolva az emlékek különböző elemeit, melyek agyunk különböző területein tárolódnak (Kónya, 200; 2001) (Squire, Cohen és Nadel, 1984; Squire, 1992 idézi Atkinson és Hilgard, 2005) (Fonyó, 2011).

Az amygdala a halántéklebeny mélyén elhelyezkedő mandulaalakú idegsejt képződmény, mely a limbikus rendszer része. A limbikus rendszer pedig koordinálja a hosszú távú memóriát, a viselkedést és az érzelmeket. Ezzel egy, a mindennapjainkban megtapasztalt és számos empirikus kutatás által bizonyított összefüggés élettani, fiziológiai hátterét találtuk meg: emlékeink és érzelmeink elválaszthatatlan, szoros kapcsolatban állnak egymással. Így belső világunk (Freund, 2011) képes egy időgéphez hasonlóan komplex emlékek sorának felidézésére. Az állandó hosszú távú tár pedig az agykéregben helyezkedik el, elsősorban azokon a területeken, amelyeken az érzékleti információk értelmezése folyik (Zola-Morgan és Squire, 1990; Szabó, 1995; Squire, 1992 idézi Atkinson és Hilgard, 2005).

\footnotetext{
${ }^{12}$ Élettan SH Atlasz, Springer Hungarica Kiadó, 1994. Budapest. 302. o.

${ }^{13} \mathrm{http}: / /$ www.unz.org/Pub/TEDxTalks-2011-01373
} 
Freund Tamás (2011) mindezeket a kapcsolódási pontokat, érzelmeinket, motivációinkat, több ezer éves kulturális örökségünket együttesen belső világunknak nevezi. És most újfent egy alapvetően lényeges gondolata következik: belső világunk az agyi hullámtevékenység befolyásolásán keresztül van hatással arra, milyen hatékonysággal tanulunk, milyen mélységben raktározzuk el (akár nem tudatosan) a kapott, észlelt információt és a memóriába került információ mennyire lesz előhívható. A kreatívan, alkotó módon gondolkodó tevékenység alapfeltétele, hogy hozzáférjünk a memóriában tárolt információ anyagokhoz ${ }^{14}$.

Doktori munkám egyik látens, mély kérdése, hogyan lehet élővé, elevenné tenni a tudományt? Mi a feltétele az információk nagyon hosszú távú memóriába való bekerülésének? Hogyan lehet élővé, izgalmassá, maradandóan személyiségformálóvá tenni az iskolát? A feltett kérdésre a válasz: az ősi agyi struktúrák aktiválásával, melyek befolyásolják az agyi alapaktivitást, az agyi hullámtevékenységet, szinkronizálják az egész kéreg müködését, azaz a háromdimenziós érzékelést odavarázsoló élő, eleven történetekkel, játékkal, müvészeti tevékenységek végzésével (Kolosai, 2012) $\left(1\right.$. kép) ${ }^{15}$.

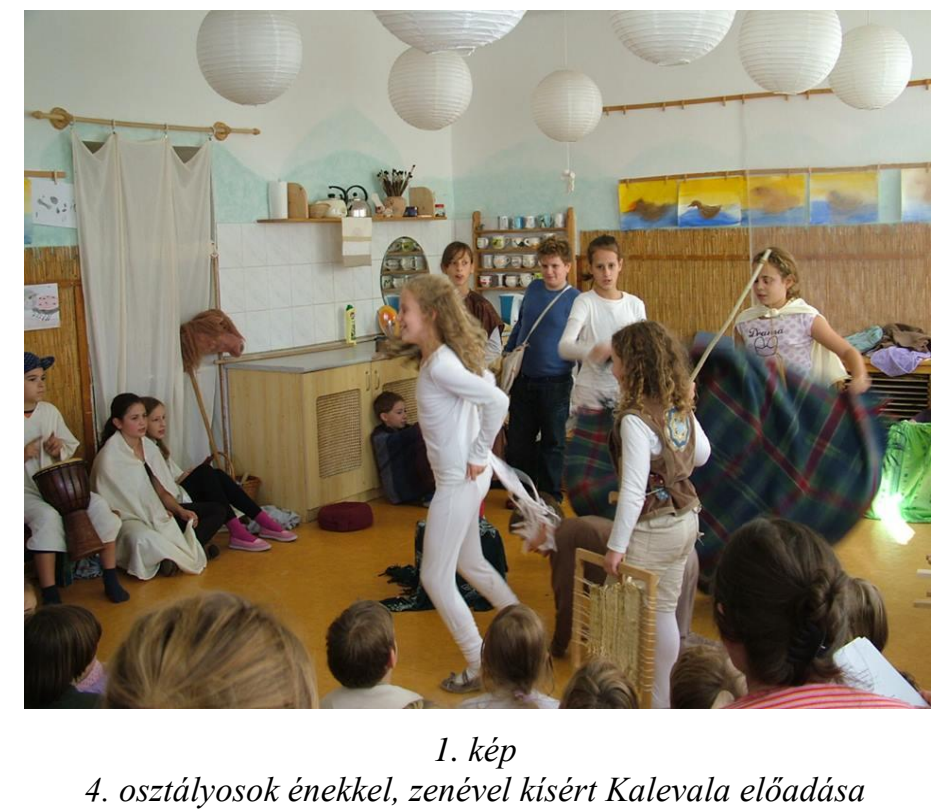

Amennyiben elfogadjuk Freund Tamás, Gerald Hütler professzor és kutatótársaik eredményeit, akkor mindebből fontos önnevelési és nevelési feladatok következnek a kreativitás, az alkotó gondolkodás, egyben a gyermeki tanulás szakszerű segítése érdekében, pedagógusok és szülők számára. Először is a gyermekben meg kell teremtenünk az arra vonatkozó igényt, hogy hagyjon időt magának saját belső világa bevonására ${ }^{16}$ a tanulási folyamat során.

\footnotetext{
${ }^{14}$ http://www.unz.org/Pub/TEDxTalks-2011-01373

${ }^{15}$ A fényképet Kolosai Nedda készítette 2013 novemberében

${ }^{16} \mathrm{http} / / /$ www.unz.org/Pub/TEDxTalks-2011-01373
} 
Ez a pedagógustól szaktudást, szakmai hozzáértést, a gyermekkel töltött minőségi idő eltöltését kívánja meg. Mindezek manapság - a nagyon drága játékszerek, elektronikus játékok és filmek özönében - a legnagyobb, egyben legdrágább adományok, a legnehezebben megvalósítható feladatai pedagógusoknak, szülőknek egyaránt miközben mindez a gyermekek jogos igénye. Ugyanakkor minél korábban kezdődik el a folyamat, annál eredményesebb.

Hogyan alakíthatunk ki olyan képességeket a ránk bízott gyermekekben és fiatalokban, amelyekkel egész további életüket tartalmasabbá és értékesebbé tehetik - ez ma a kultúra, a gyermekkultúra egyik leglényegesebb kérdése is (Klinborg és Calgren, 2003; Végh, 2013).

Az információrobbanás, a globalizáció nyújtotta információ áradat a kulturális örökség nem megfelelő átadását eredményezi, mondja Freund Tamás. Mindannyiunk tapasztalata, hogy az interneten szörfözve rengeteg felületes információ birtokába jutunk, már el is felejtjük mit is akartunk, mi volt a kiinduló kérdésünk, csak úgy folytatjuk tovább a böngészést.

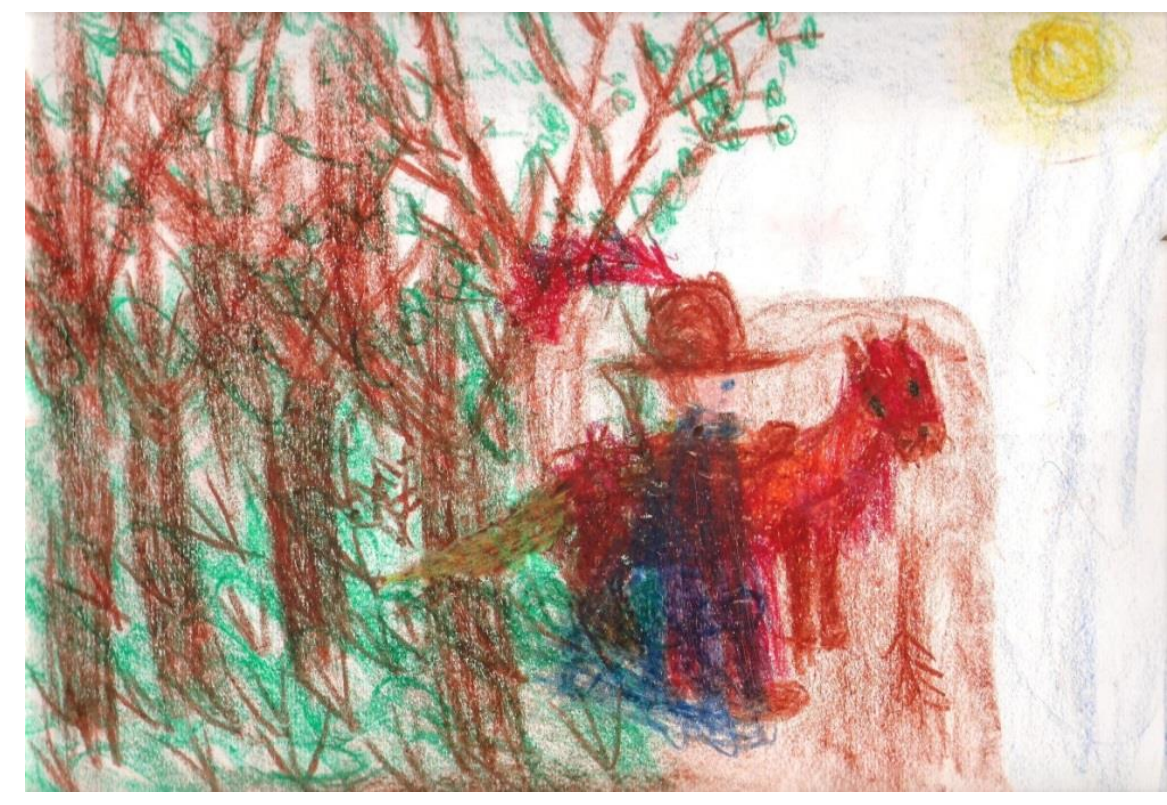

2. kép

Nyolc éves kislány rajza. Egy lovag a szakadék széléhez érkezik.

A felületes memóriaraktárainkat kitöltjük egy olyan bizonytalan anyaggal, melyhez nem kapcsolódnak kellően mély érzelmek, nincs idő bevonni a belső világot. Az így szerzett információból új, eredeti gondolatok nem keletkeznek, pillanatok alatt elfelejtődnek, ez pedig a sikertelenség és frusztráltság érzését kelti. Mindez a krónikus stressz kialakulásával civilizációs lelki betegségek megjelenéséhez vezethet; pánik, szorongás, depresszió kiindulópontjaivá válhat, mondja Freund Tamás ${ }^{17}$. Veszélyeztetettek ebben a folyamatban a tizenkét évesnél fiatalabb gyerekek, ezen belül is a kiskamaszok.

\footnotetext{
${ }^{17}$ http://www.unz.org/Pub/TEDxTalks-2011-01373
} 
A müvészetek müvelése, a müvészettel nevelés prevenciós szerepet tölt be az iskolai és óvodai mentális egészségnevelésben. A művészetek művelésének lelki egészséget védő szerepét a pszichológia tudománya megszületése óta hirdeti. Tekintsük át ezeket az elgondolásokat, melyek más perspektívákból állítják évtizedek óta azt, amit a jelen agykutatásai müszeres eljárásokkal igazolnak.

Amikor a gyermek müvészeti tevékenységgel fejezi ki érzelmeit és élményeit, először is „kifújja a gőzt”, ez az elaboráció, más terminusban szublimáció folyamata, mely során (ösztön)energiáit egy társadalmilag elismert tevékenységben dolgozza át (Freud, 1982; Mérei, 2002; Hermann, 2003; Krisztián, 2011). Sigmund Freud a lélek természetvédelmi parkjának nevezte a szabad képzeletvilágot, azt javasolta, tápláljuk ennek eröit gyermekinkben is (Freud, 1982). A müvészeti élmény átélése közben a lélek szellőzködik, vágyai leheletfinoman lélegzenek a szimbólumok erdejében vagy virágoskertjében mondja Bagdy Emőke (2013). Azonban, ennél is több történik müvészeti tevékenység végzése közben. A gyermek alkot, létrehoz és ez az alkotás és létrehozás nem csak a tárgyak világában történik meg, hanem lelkében, belsőjében, személyiségében is (Klinborg és Calgren, 2003). Amit a szimbolikus gondolkodás kifejezési nyelvén megfogalmazunk, az maradandó változást indukál a jelentésszervező és a memóriarendszerben (Bagdy, 1995/96) egyaránt. A müvészeti tevékenység ebben a pszichológiai kontextusban tükör a pedagógus számára, tükör az alkotó gyermek számára és tükör a gyermekközösség tagjai számára egymásról. Ebben a tükörben olyan részletei mutatkoznak meg a személyiségnek, melyek eddig rejtve voltak, mert nem volt szemünk a megpillantásukra, fülünk a meghallásukra. Alapvetően fontos hangsúlyozni, hogy a szimbólumok interpretatív felfejtése, a verbális jelentéskeresés, nem lényegi elem ebben a mentális egészségvédő munkában, legfeljebb értékes többlet. A szimbolikus, legtöbbször képi-képzeleti szinten létrejövő megértés önmagában

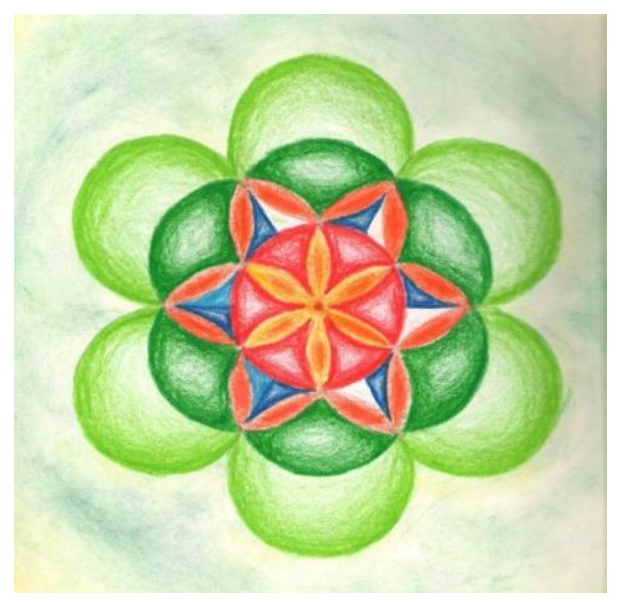

3. kép

Virágforma, 11 éves lány munkája.

Geometria, természet és müvészet. kedvező folyamatokat, kedvező változásokat gerjeszt, valamint energetizálja a személyiséget (Bagdy, 2013).

Izgalmas és fontos tényező a müvészeti nevelés lelki egészséget megőrző szerepében a mủvészetek művelésének közösségteremtő aspektusa. Az önreflexió mellett a müvészeti tevékenység végzése közbeni dialógus, a másik emberre való rácsodálkozás, a másik emberben való önfelismerés lehetősége az, ami közösségteremtő (Trencsényi, 2000).

Fontos visszakanyarodnunk annak a kérdésnek a megvilágításához, hogy a művészetek végzése lelki egészségvédő szerepén túl, hogyan segíti a tanulás folyamatait. Az agy szempontjából a környezet maga az információ, s mint minden rendszer az agy is alkalmazkodik környezetéhez. A környezet megváltozásának mértéke mindenkor meghatározza, 
mekkora az adaptációs és szelekciós nyomás. A környezethez való alkalmazkodásukat gátolja, lelki egészségüket veszélyezteti, amennyiben a gyerekek nincsenek felkészülve arra, hogy a tanulási folyamat során hagyjanak időt belső világuk bevonására. Ugyanilyen veszélyeket rejt az alkalmazkodás szempontjából, amennyiben nincs mit társítaniuk az információ tengerhez, mert esetlegesen szegényes a gyermekek belső világa.

Tehát alapvetően fontos, hogy gazdagítsuk a belső világot. Művészeti neveléssel, etikai, erkölcsi neveléssel, a költészet eszközeivel, színjátszással, festéssel, szobrászkodással szükséges gazdagítanunk a gyerekek belső világát vallja Freund Tamás agykutató is. Ebben a folyamatban, a belső világ gazdagításában nagy szerepe van a felnőttnek, nagy szerepe van a pedagógusnak.

Szükség van karizmatikus pedagógus személyiségekre - olyan tanítókra, óvoda-pedagógusokra, kisgyermeknevelőkre, egyetemi oktatókra, tanárokra -, akik képesek katartikus élményekhez juttatni a rájuk bízott gyerekeket, diákokat ${ }^{18}$. Ehhez élö, eleven, lendületes módszerekkel szükséges közelíteni a gyerekekhez (Ornstein, 1997; Jalongo, Rieg és Helterbran, 2007), mert a fent felsorolt

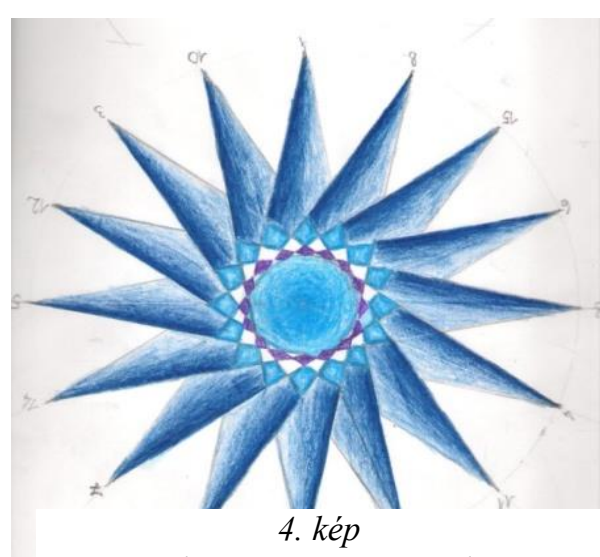

12 éves lány geometriai szerkesztése tényezők gazdagítják a gyerekek belső világát rendkívüli módon.

A pedagógusképzésben szükséges azokra a mindennapi pedagógiai gyakorlatban lényeges kompetenciákra helyezni a hangsúlyt - például a hatékony és szuggesztív közlésre és kiállásra -, melyek közös elemeket tartalmaznak a müvészi közlés sajátosságaival. Ebben a kontextusban gondolkodhatunk és beszélhetünk a tanításés nevelés müvészetéröl ${ }^{19}$.

Nézzük, hogyan gazdagítja a művészeti tevékenység azt a bizonyos belső világot? Amikor a gyerek például fest egy határtalan új világba lép, közben saját belső világa is megváltozik, kitágul. Mit is jelent az ember egész későbbi élete szempontjából az intenzív színélmény? Valami kézzel nem tapintható belső gazdagságot, igényességet, árnyalt látásmódot, melyeket nehéz szavakba önteni. Aki a színek néma nyelvéből megtapasztalt, átélt, meg- és átérzett valamit egészen másként látja a világot.

\footnotetext{
${ }^{18}$ http://www.unz.org/Pub/TEDxTalks-2011-01373

${ }^{19} \mathrm{http} / / /$ www.tani-tani.info/toprengesek_a_tanitoi Érdemes a témában elolvasni Knausz Imre Mi a nevelés? címü írását. www.tani-tani.info/mi_a_neveles
} 
A színekhez intellektuálisan közelíteni nem lehet, mégis páratlanul mély benyomást gyakorolnak a tevékeny létrehozóra és a szemlélőre egyaránt

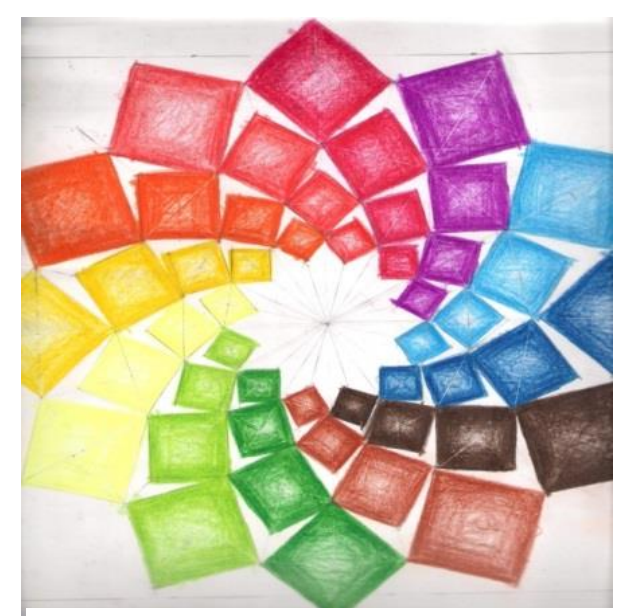

5. kép

Geometria, matematika és müvészet. 12 éves lány munkája.

(Klinborg és Calgren, 2003). Egy müvészeti ág gyakorlása olyan összetett problémák elé állít bennünket, amelyet általában a mindennapok, az élet is felvet. Attól függően, hogy milyen anyaggal dolgozik a gyermek festékkel, fával, agyaggal, irodalmi alkotással, mozdulattal, addig nem tudja megoldani a feladatot, amíg nem oldódik fel az anyagban, amíg nem tiszteli az anyagot.

Ez a fajta beleélési folyamat egész sor lelki mozzanatot foglal magába. Várakozást, töprengést, meglepődést, dühöt, újbóli reménykedést és tervkészítést, újabb akaratmegfeszítést, az alkotás ujjongó örömét. Nem csak a lélek vesz részt a müvészeti alkotásban, a test is részese a folyamatoknak, az ujjak, hangszalagjaink, egész testünk, legapróbb porcikáink. Tehát az értelem fejlesztése gyermekkorban (1-12 éves korban) az egész test ügyes kezelésének gyakorlásából ered, nem bifláztatásból (Vekerdy, 2002; Hüther, 2009; Klinborg és Calgren, 2003).

A müvészi tevékenységek végzése erőteljesen hat az érzékelésre, megmozgatja a teljes érzelmi apparátust, működésbe lendíti a fantáziát ugyanakkor felkészíti a gyermeket a komplex problémamegoldásra, gondolkodását, értelmi erőit egyaránt mozgásba lendíti.

\section{Epilógus}

Oly korban élünk, melyben elfogadott, királyi tudománynak a természettudományok számítanak, a bölcsészettudományok és a müvészetek pedig egyfajta luxusnak. Agykutatók természettudományos módszerekkel és szemlélettel bizonyították, kutatásaik eredményeivel folyamatosan bizonyítják, hogy az emberi tanulás alapfeltétele az információkhoz társított belső világ, az emberi tanulás alapfeltétele tehát a müvészetek müvelése. A természettudományok így valóban rendkívül hasznosnak bizonyultak abban, hogy megértsük a müvészetek életünket folyamatosan alakító erejét, az ember ősi elementáris vonzódását ahhoz, ami mélyen emberi. A pedagógusképzés feladata együttes művészeti-, kreatív tevékenységekkel, közösségi élményekkel, gyakorlat közeli módszerekkel ${ }^{20}$ továbbadni ezt a tudást. Az ELTE Tanító- és Óvóképző Kara felvállalja a feladatot évtizedek óta. Hallgatóinak magas színvonalú müvészeti képzésével, valamint a müvészeti nevelés tudományos, elméleti megközelítéseinek, a legfrissebb kutatások eredményeinek átadásával, egyfajta mediátor szerepben segíti az 1-12 éves gyermekek szakszerü oktatását és

\footnotetext{
${ }^{20}$ http://www.tani-tani.info/toprengesek_a_tanitoi
} 
nevelését (Bánki és Bálványos, 2005; Mikonya, 2010, 2013; Döbrössy, 2011; Bakos, Bálványos, Preisinger és Sándor, 2012; Kismartony, 2012; Darvay, 2012; Pataky, 2012). Nem a müvésszé nevelés, hanem az alkotó emberré nevelés a képzés célja.

Összefoglalva, a nevelésnek fontos megteremtenie a gyermekben az igényt és a feltételeket a belső világ bevonására a gyermek tanulási folyamataiba, egyben müvészeti neveléssel; festéssel, színjátszással, kórusban énekléssel, szobrászkodással pedagógusként gazdagítanunk kell a belső világot. Ennek a nevelési célnak a megvalósításához szükség van olyan magasan képzett, karizmatikus pedagógus személyiségekre, akik élő, eleven módszerekkel, színesen, mozgalmasan képesek a gyerekeknek megmutatni a világot, művészi módon, mesterfokon müvelni a nevelést.

\section{Irodalom}

Atkinson, Richard és Hilgard, Ernest (2005, szerk.): Pszichológia. Osiris Kiadó, Budapest. 123-127.

Bagdy Emőke (1995/96): Állapotkép -Szimbolikus müalkotás a terápiában. In: Bagdy Emőke, Bognár Andrea és Urbánné Varga Katalin (szerk.): Müvészetek - szimbólumok - terápiák. Glória, Budapest. 111-131.

Bagdy Emőke (2013): Álmok, szimbólumok, terápiák. Kulcslyuk Kiadó, Budapest.

Bakos Tamás, Bálványos Huba, Preisinger Zsuzsa és Sándor Zsuzsa (2012): A vizuális nevelés pedagógiája a 6-12 éves korosztályban. Eötvös Kiadó, Budapest.

Bánki Vera és Bálványos Huba (2005): Differenciálás a müvészeti nevelésben. OKKER, Budapest.

Darvay Sarolta (2012, szerk.): Tanulmányok a gyermekkori egészségfejlesztés témakörben. Eötvös Loránd Tudományegyetem, Budapest.

Dilthey, Wilhelm (2004): Gondolatok egy leíró és taglaló pszichológiáról. In: (uö): A történelmi világ felépitése a szellemtudományokban. Gondolat, Budapest.

Döbrössy János (2011, szerk.): Ének-zene-nevelés. Trezor Kiadó, Budapest.

Fonyó Attila (2011): Az orvosi élettan tankönyve. V. kiadás. Medicina Könyvkiadó Zrt., Budapest.

Gadamer, Hans-Georg (1984): Igazság és módszer. Gondolat, Budapest.

Geertz, Clifford (1994): Az értelmezés hatalma. Századvég, Budapest. 170-200., 352-369.

Einstein, Albert (2013): Hogyan látom a világot? Gladiátor, Budapest.

Endrődy-Nagy Orsolya (2013): Középkor és reneszánsz. - Adalékok egy lehetséges gyermekképi paradigmaváltáshoz. Gyermeknevelés, 1. 1. sz. 63-72.

Heidegger, Martin (1927/2001) Lét és idö. Budapest.

Hermann Alice (2003): Az ösztönök megnevelése. In: B. Lakatos Margit és Serfőző Mónika (szerk.): Pszichológia-Szöveggyüjtemény óvodapedagógus hallgatóknak. Trezor Kiadó, Budapest.

Hüther, Gerald (2009): Digitális média és gyermeki agy - Virtuális világok büvöletében. Élet és tudomány, 63. 13. sz. 405-408. 
Fehér M. István (2009): Hermeneutika és humanizmus. In: Nyírő Miklós (szerk.): HansGeorg Gadamer - egy 20. századi humanista. L'Harmattan Kiadó, Budapest. 43-118.

Freud, Sigmund (1982): Leonardo da Vinci egy gyermekkori emléke. In: Esszék. Gondolat Kiadó, Budapest. 253-327.

Freund Tamás (2011): Agyhullámok és kreativitás. előadás. letöltés helye: http://www.unz.org/Pub/TEDxTalks-2011-01373 letöltés ideje: 2013. március 15.

Gardner, Howard (1993): Multiple Intelligences: The Theory in Practice. Basic Books.

Illés Anikó (2009): Művészetterápia a közoktatásban: elméleti lehetőségek és etikai megfontolások. Új Pedagógiai Szemle. 5-6. sz. 233-240.

Jalongo, M. R., Rieg, S. A., és Helterbran, V. R. (2007). Planning for learning: Collaborative approaches to lesson design and review. Teachers College Press New York.

Kárpáti Andrea (1991): Látni tanulunk. Akadémiai Kiadó, Budapest.

Kismartony Katalin (2012): Gesztusok a zenében. In: Varga László (szerk.): Humántudományi kutatások a pedagógusképzés szolgálatában. Generációk találkozása. NYME BEPK, Sopron. 96-102.

Kiss Virág (2013): Művészeti nevelés, művészettel nevelés, művészetterápia. Iskolakultúra, 10. 18-31.

Kolosai Nedda (2011): Komolyan venni a játékot - Pedagógiai segítő munka a mentálisan sérülékeny szülők gyermekeivel és családjával. In: F. Lassú Zsuzsa (szerk.): Gyermekek mentálisan sérülékeny családokban - Kézikönyv pedagógusoknak. ELTE Eötvös Kiadó, Budapest. 147-186.

Kolosai Nedda (2012): Kisiskoláskor és történeti idö - Az 1950-es évek kisiskoláskorára vonatkozó narrativák tartalomelemzése - Doktori $(\mathrm{PhD})$ disszertáció, ELTE Pedagógiai és Pszichológiai Kar, Neveléstudományi Doktori Iskola, Budapest.

Kolosai Nedda (2013): Miért nehéz az iskolatáska? In: Változó életformák - Régi és új tanulási környezetek. Pedagógusjelöltek szomatikus és pszichés állapotának felmérése, pályaszocializációjuk és elhivatottságuk mutatói az ELTE Tanító- és Óvóképző Karán című szimpózium előadása, 2013. november 8. Országos Neveléstudományi Konferencia, Eger.

Koselleck, Reinhart (2003a): Elmúlt jövö - A történeti idök szemantikája. Atlantisz Kiadó, Budapest.

Koselleck, Reinhart (2003b): „Tapasztalati tér” és „várakozási horizont” - két történeti kategória. In: (uő.): Elmúlt jövő - A történeti idők szemantikája. Atlantisz Kiadó, Budapest.

Kónya Anikó (2000): Az érzelem az emlékezet nyílt és rejtett felosztásában. In: Pléh Csaba, Kampis György és Csányi Vilmos (szerk.): A megismerés kutatás útjai. Akadémiai Kiadó, Budapest. 157-169.

Kónya Anikó (2001): Miként gondolkodunk az emlékezetröl. In: Oláh Attila és Bugán Antal (szerk.): Fejezetek a pszichológia alapterületeiböl. ELTE Eötvös Kiadó, Budapest. 65-98.

Krisztián Ágota (2011): A varázsló trükkjei. In: B. Lakatos Margit (szerk.): Játékpszichológia. ELTE Eötvös Kiadó, Budapest. 205-211.

Laczó Zoltán (2001): Zenei nevelés a közoktatásban. In: Báthory Zoltán és Falus Iván (szerk.) Tanulmányok a neveléstudomány köréböl. Osiris Kiadó, Budapest. 437-451.

Lánczos Kornél (1973/2011): A tudomány, mint a múvészet egyik formája. Fizikai Szemle, 2001. 5. 4. sz. letöltés helye: 
http://members.iif.hu/visontay/ponticulus/rovatok/hidverok/lanczos.html letöltés ideje: 2013. december 6.

Loboczky János (2009): Gadamer és a zene. In: Nyírő Miklós (szerk.): Hans-Georg Gadamer-egy 20. századi humanista. L'Harmattan Kiadó, Budapest. 223-233.

Mészáros György (2010): Új episztemológiák kihívása a neveléstudományban. Iskolakultúra, 19. 1. sz. 14-34.

Mérei Ferenc és Binét Ágnes (2002): Az indulatok feldolgozása gazdagítja az érdeklődést, és emeli a teljesítmény színvonalát. In: Gyermeklélektan. Gondolat, Budapest. 273-282.

Mikonya György (2010): Tanításművészeti mühelyek a pedagógusképzésben. In: Baráth, L. és Viczayová, I. (szerk.): Tudomány az oktatásért - oktatás a tudományért. International conference in honour of 50 years of Hungarian teacher training in Nyitra konferencia tanulmánykötete, Közép-európai Tudományok Kara, Nyitra. 151-161.

Mikonya György (2013): A tánctanulás és a tánctanár-képzés motivációs rendszerének vázlata. In: Karlovitz János Tibor és Torgyik Judit (szerk.): Oktatás, kutatás és módszertan. International Research Institute s.r.o., Komárno.

Ornstein, Allan C. (1997): How teachers plan lessons. High School Journal, 55. 80. sz. 227-238.

Pataky Gabriella (2012): Vizuális képességek fejlödése 6-12 éves korban, a tárgykultúra tanitásának területén. ELTE Tanító- és Óvóképző Kar, Budapest.

Proust, Marcel (2009): A megtalált idö. Atlantisz Kiadó, Budapest.

Szabó Csaba (1995): Tanulás - Emlékezés. KLTE, Debrecen.

Szabó Mónika (2004): Motiváció. In: N. Kollár Katalin és Szabó Éva: Pszichológia pedagógusoknak. Osiris Kiadó, Budapest. 169-192.

Thurmezeyné Heller Erika és Balogh László (2009): Zenei tehetséggondozás és képességfejlesztés. Kocka Kör, Nyitra: Faculty of Central European Studies, Constantine the Philosopher University, Debrecen.

Tolsztoj, Lev (2010): Mi a müvészet? Európa Könyvkiadó, Budapest.

Trencsényi László (1991, szerk.): Világkerék - Komplex müvészetpedagógiai projektek az Iskolafejlesztési központ gyüjteményéböl. OKI-IFA, Budapest.

Trencsényi László (2000): Elmélet, elméletek a müvészetpedagógiákban. In: (uő.): Müvészetpedagógia - Elmélet, tanterv, módszer. OKKER Kiadó, Budapest. 7-44.

Trencsényi László (2002): Hasznos múlattató. Új Pedagógiai Szemle, 52. 12. sz. 160-163.

Trencsényi László (2011): Töprengések a tanítói tehetségről - avagy egy civil tanévnyitó.

Tani-tani online, 16. 2. 2 sz. letöltés helye: http://www.tanitani.info/toprengesek_a_tanitoi letöltés ideje: 2013. június 15 .

Vekerdy Tamás (2002): Széchenyi. In: (uő.): Kérdezz! Felelek... Park Kiadó, Budapest. 188-190.

Végh Balázs Béla (2013): Képes vagy képtelen? Korunk, Gyermekkultúragyermekirodalom, 3. 9. sz. 59-64.

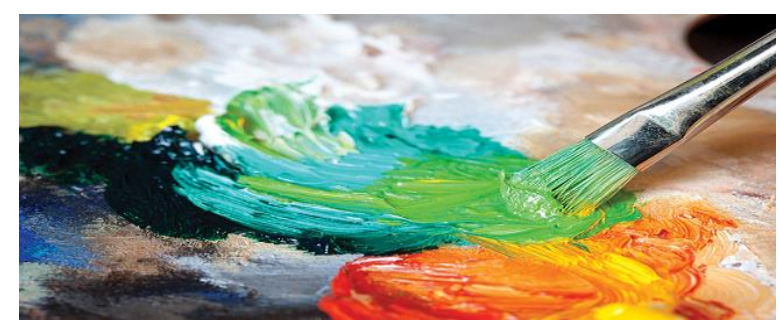

